\title{
The Potential of Bait al-Māl wa Tamwil (BMT) in Developing The Border Area of Indonesia - Malaysia
}

\author{
Muhammad Iqbal Maulana ${ }^{1}$, Nashr Akbar ${ }^{2}$
}

\begin{abstract}
This research aims at investigating the potential of Bait al-Māl wa Tamwil (BMT) in the development of border areas of Indonesia-Malaysia by prioritizing the welfare approach. Primary data was obtained through in-depth interviews with respondents from academics, practitioners, and regulators. The Analytic Network Process (ANP) method and Benefit Opportunity Cost Risk (BOCR) network are used to review the interview results. The results reveal that BMT is able to help the development of the border areas. Moreover, the aspects of benefit and opportunity in exploiting BMT is more significant than the cost and risk aspects. There are three alternative strategies to be implemented in order to maximize the benefits and opportunities and also minimize the costs and risks, namely the capital of third parties, linkage programs, and special regulations.
\end{abstract}

Keywords: $A N P-B O C R, B M T$, Border Area

\begin{abstract}
Abstrak. Penelitian ini mengkaji potensi Bait al-Māl wa Tamwil (BMT) dalam pembangunan di wilayah perbatasan Indonesia-Malaysia dengan memprioritaskan pada pendekatan kesejahteraan. Data primer penelitian ini diperoleh melalui wawancara mendalam dengan responden yang berasal dari akademisi, praktisi dan pembuat kebijakan. Metode Analytic Network Process (ANP) and Benefit Opportunity Cost Risk (BOCR) network digunakan dalam analisis hasil wawancara. Dalam studi ini ditemukan bahwa BMT berpotensi untuk dapat membantu pembangunan di wilayah perbatasan, Selain itu, aspek manfaat dan peluang dari pemanfaatan BMT lebih signifikan daripada kerugian dan resikonya. Ada tiga strategi alternative yang dapat diimplementasikan untuk memaksimalkan manfaat dan peluang dari BMT dan juga meminimalisir kerugian dan resikonya, yaitu modal pihak ketiga, keterkaitan antar-program, dan peraturan-peraturan khusus terkait.
\end{abstract}

Kata kunci: $A N P-B O C R, B M T$, Border Area 


\section{Introduction}

The economic crisis that hit Indonesia in 1998 affected the economy in every province. The deteriorating economic performance then affected various aspects of community life in the socio-economic spheres, such as problems of income distribution, employment, and poverty (Suratman, 2008). This crisis has had an impact on the level of people's welfare in the region. Various policies had been taken by the government to alleviate the national economic problems and to survive the crisis. Law No. 25 of 2000 on the National Development Program (PROPENAS) mentions that the priorities of national development should be planned, comprehensive, integrated, directed, gradual and continuous. At the same time, the Medium-Term Development Plan (RPJM) of 2004-2009 mentions some criteria of the regions that are still experiencing inequality in development. One of the regions is the border area of Sambas Regency in West Kalimantan (Indonesia) with Sarawak (Malaysia).

The border areas are generally distant from the central government. Social and economic disparities often arise as a result of different treatments from the central government, and even more complex in these areas compared to other areas. Thus, intervention and special treatment from the government are required to solve the problem (Ishak, 2003). This is because the level of vulnerability of border areas is higher than of other regions. Unanticipated social and economic gaps will interfere and affect the pattern of national development strategies and will have an impact on national interests. Indonesia's fundamental national interest is the survival of the nation and the Unitary State of the Republic of Indonesia based on Pancasila and the 1945 Constitution. The national interest also concerns with the border areas and all of the related issues (Ishak, 2003).

According to Mayona et al. (2011), the gaps are due to the past assumption that the border areas were considered to be hideouts of insurgents and smugglers. This made the priority of the developmen $t$ is focused on security rather than prosperity aspects. The impact has been the isolation of the border areas from the dynamics of development. This has caused the poverty and lagging of the surrounding community.

This differences of the socio-economic condition in Indonesia-Malaysia border areas can cause negative effects that tend to harm the people (Bangun, 2014). It is necessary to develop the areas and prioritize the welfare of the people, but still pay attention to the security aspects (Ishak, 2003). The concept of welfare, according to Nasikun (1993), can be seen from four indicators, namely security, welfare, freedom, and identity. 
Bait al-Māl wa Tamwil (BMT) is expected to be alternative means in prioritizing the welfare development of Indonesia's border regions (West Kalimantan, Sambas) that are contiguous with Malaysia (Sarawak). Huruswati et al. (2012) said that the acceleration of economic growth in the border regions is needed. One measure that could be taken is to revive the role of microfinance institutions supported by empowerment, assistance, and strengthening community participation in socio-economic activities. Related to that, BMT plays roles in conducting, coaching, and funding, sharia-based socio-economic activities. Thus, it is expected that BMT encourages the emergence of new economic centers to reduce poverty (Sriyana and Raya, 2013).

So, the purpose of this research is to know and analyze the aspects of benefit, opportunity, cost, and risk (BOCR) that will be obtained by the society with the existence of BMT in developing border areas of Indonesia and Malaysia. This research will also identify which aspects that have a greater role than every BOCR if BMT is optimized to develop the border regions. The last is to acknowledge the strategies to be taken by BMT to enlarge its potential in developing border areas of Indonesia-Malaysia.

\section{Literature Review}

\section{Theory and Concepts of Bait al-Māl wa Tamwil (BMT)}

Bait al-Māl wa Tamwil is a Sharia Micro Financial Institution (Lembaga Keuangan Mikro Syariah) commonly abbreviated as BMT and is the synonym of the Integrated Independent Business Center. BMT consists of two entities, namely Bait al-Māl, which means funding house, and Bayt al-Tamwīl, which means house of business. The current Bait al-Māl is the replica of the Bait al-Māl that as developed in Islamic history since the time of the Prophet, where its function was to collect and channel social funds. Meanwhile, bayt al-Tamwil is an institution that provides financial services with a motive to obtain profits. Thus, BMT is not an institution that only distributes the social funds, but also plays a role as a social role of the business institution (Hafifuddin, 2003).

Ridwan (2005) defines Bait al-Māl as an organization in charge of collecting, managing and distributing zakat, infāq, and sadaqah for social-oriented purposes. Moreover, bayt al-Tamwil is an institution in charge of collecting, managing and channelling funds for profit-oriented purposes, with economic activities that involve profit sharing (qirād or Mudārabah, syirkah or musyarakah) or rent (Ijärah). In general, BMT means a Sharia Micro Finance Institution (SMFI) which operates using the principle of profit sharing. BTM cultivates micro businesses for the 
benefits of the poor and grows initial capitals of local community leaders based on the justice-oriented economic system (Hosen, 2006).

The presence of Bait al-Māl wa Tamwil (BMT) is the result of the concern of the Small Business Incubation Center (PINBUK). Through various lengthy and in-depth studies, a finance system is formulated; this system is expected to suit the microenterprise conditions and in accordance with sharia. The financial system is the BMT (Ridwan, 2005). According to Danupranata (2006), the administrative and working mechanisms of BMT have similarities with the Sharia Credit Bank (BPR), despite having different scopes and products. Yunus (2009) explained that Bait al-Māl wa Tamwil (BMT) is two institutions that become one, namely Bait al-Māl institution and Baitut Tamwil institution. The two have different principles and products despite a close relationship between the two institutions in creating equitable and dynamic economic conditions. To be able to achieve them, the financial institutions, which can reach the grassroots, are needed.

In running a business, Ridwan (2005) said that BMT should maintain the main principles, namely:

1. Faith and devotion to Allah by applying the principles of sharia and muamalat in real life;

2. The integration between spiritual and moral values in operating dynamic, proactive, progressive, fair, and noble.business ethics;

3. The kinship that prioritizes mutual interests above personal interests;

4. Togetherness, i.e. unity of mindset, attitude, and ideas of all elements of BMT;

5. Independent, i.e. independent from all political parties, and loan funds and assistance, but still proactively raise public funds as much as possible;

6. Professionalism, which is high morale based on faith. So, working is not only for the worldly life but also for the afterlife.

7. Istiqämah or consistent, continuing without ends, and despair; and advancing to the next stage right after reaching one, for the sake of the Devine.

\section{Concept of Border Area}

The border area is a region that is geographically bordered directly with neighboring countries and directly confronts other countries (Sudibyo, 2006). According to Law No. 43 of 2008 on State Territories, the border area is part of the country's territory located on the inside of Indonesia's territorial, contiguous with other countries. In the case of on-land areas, the border area is in sub-districts. The border area is an area geographically adjacent to neighboring countries, whether 
located on land, sea, or air, which have functions related to security, prosperity, and environment (Dardak, 2007). Mukti (2003) adds that the border area is an area that is strategically potential for the development of mutually beneficial for international trade activities. The border area also has great potentials to become the center of regional growth, especially in terms of industrial development, trades and tourism. These provide opportunities to increase production activities, which will further generate multiple effects for the welfare of the community.

There are three strategic issues concerning the development and establishment of border areas when viewed from the economic aspect (Sumarsono, 2012): 1) the environmental damage due to uncontrolled natural resources management; 2) the gaps in facilities and infrastructure of the border regions with the neighboring countries; 3 ) and the limited facilities and supporting infrastructure for economic activities. According to Kurniadi (2009), the development of border areas is closely related to regional economic growth, which is also related to trading activities in the region. Inter-state border areas, according to Hamid (2003), are strategic areas because they own a regional and national economic growth point.

Through border areas, inter-country trade activities can be done easily, quickly and cheaply. However, when will the economic activities of the regions with the neighbour country have an impact on community production activities, income, and welfare? Trading activities and the need for some products can be used as an engine to improve the welfare of the people in the border areas (Djafar, 2008). This is in accordance with the direction of border development policy based on Presidential Regulation No. 5 of 2010 concerning the National Medium-Term Development Plan (RPJMN) 2010-2014, which is to make the border area as the front porch of the state, as well as the gate of economic and trade activities with neighboring countries in an integrated manner.

\section{Previous Research}

Afrizal (2009), in his research entitled Potential of Micro, Small and Medium Business Financing by Banks in West Kalimantan Border Area Year 2008, explains that trade, agriculture and services dominate economic activities running in the border areas (Entikong and Sajingan Besar). However, the economic activities in the border areas are still small, and formal financial services institutions are less available, only limited to Credit Union. Out of that, the actors of MSME still have a negative attitude toward banking because they consider the banking procedures and requirement complicated. This is also exacerbated by the limited infrastructures and unavailability of a market as a place for the public transaction, especially in 
Kecamatan Sajingan Besar (Sambas). Kecamatan Entikong (Sanggau), on the other hand, has a relatively better infrastructure and market.

Susila (2014), in his research entitled The Success Strategy of Cooperative BMT Maslahah in Business Development and Economic Empowerment of society, adds that BMT could strengthen and develop MSME financing, especially in a small society. In addition, the BMT's cooperation with MSMEs in the field of capital can expand the market, and contribute greatly to the national economy. Salam et al. (2014) also examine the Optimization Model of Sharia Micro Financing Institutions (SMFI) in the Framework of Rural Development and Empowerment. The study by Salam et al.'s aims at analyzing the possibility of Sharia Micro Finance Institution in developing and empowering rural area. The result of this research is that there has been a significant impact of microfinance institution on the Indonesian economy, both in the long term and short term. The use of musharaka and mudaraba contracts has become an alternative method for MSMEs to obtain capital. Yusuf (2004) also examines the Strategic Role of Bait al-Māl wa Tamwil (BMT) in people's economic improvement. Yusuf found out that BMT can be used as a solution and answer to the need for a small society for a banking institution.

Aminullah (2009) researched the Role of Bait al-Māl wa Tamwil in Achieving Member Welfare (Case Study of BMT Darussalam Ciamis West Java). The study aims to investigate the role of BMT in the welfare of its members. Aminullah (2009) found out that there are two kinds of the welfare of the member of BMT, which are material and non-material. The material aspect can be seen in the income achieved by the BMT per month. Meanwhile, the non-material welfare can be seen in the change in the life of the members both financially and non-financially. Mikhraini (2011) conducted research on Cooperatives and BMT: A phenomenon of Fund Resources for the benefit of the Ummah. This research suggests the significant role of cooperative and BMT as the sources of fund for the benefit of the umma because they uphold the value of humanity in their practice. Besides, cooperative and BMT uphold the principles of kinship, mutual assistance and mutual help so that these principles can help to create benefits for human beings to fulfil their needs and to cover the needs for business funds.

Also, Sakti (2013) conducted research entitled "Mapping the Conditions and Potential of BMT: Partnership in Order to Expand Market and Reach of Bank Sharia Services to Micro Enterprises". This research reveals that BMT has become significant and played a central role in opening access to capitals for micro-small businesses. However, BMT needs to improve its institutional and operational aspects, especially related to industrial governance and other internal aspects such as operations and management. Furthermore, there are several matters that are 
problematic for BTM, namely (a) limited capital, (b) human resources that do not support the sustainability of BMT, (c) government regulations that do not support the creation of good macro governance in BMT industry, d) people are still unfamiliar with BMT and (e) Infrastructures that are still very minimal in supporting the performance of BMT.

\section{Research Methodology}

\section{Data Sources and Data Collection}

This research uses primary data and secondary data. The secondary data is derived from various literature. While the primary data obtained through indepth interviews to obtain detailed information about the subject matter discussed in this research. From the interviews, the authors obtained data on the factors influencing the BMT and its potential in developing the border area of Indonesia (West Kalimantan, Sambas) and Malaysia (Sarawak). Respondents in this research are academics, practitioners, and regulators who understand about BMT and border areas of West Kalimantan - Sarawak.

The respondents are divided into three categories: academics, practitioners, and regulators. The respondents include:

Table 1. The Respondents of Research

\begin{tabular}{|c|c|c|}
\hline No. & Name & Position \\
\hline 1. & Dr Ichsan Iqbal, SE, MM & $\begin{array}{l}\text { Dean of Sharia and Islamic Economics Faculty of } \\
\text { IAIN Pontianak }\end{array}$ \\
\hline 2. & Dr Afrizal, SE, M.Si & $\begin{array}{l}\text { Lecturer of The Faculty of Economics of } \\
\text { Tanjungpura University }\end{array}$ \\
\hline 3. & Prof. Dr H. Eddy Suratman, SE, MA & $\begin{array}{l}\text { Professor of The Faculty of Economics of } \\
\text { Tanjungpura University }\end{array}$ \\
\hline 4. & Lies Indah Permanasari, A.Md & Head of BMT Mujahidin of Pontianak \\
\hline 5. & Jumarwan, SE & Head of Puskopsyah of West Kalimantan \\
\hline 6. & Drs. Manto Saidi, M.Si & Head Unit Administrator of PPLB Aruk \\
\hline 7. & $\begin{array}{l}\text { Oscar Rynandi Andijoe, SE, M.Si, } \\
\text { Ak.CA }\end{array}$ & Director of PINBUK of West Kalimantan \\
\hline 8. & Syahrul Aman, SE & $\begin{array}{l}\text { Section Chief of Institutional Cooperative Office of } \\
\text { Kab. Sambas }\end{array}$ \\
\hline 9. & Ir. Fachraini, SE & Secretary of BP2DT of West Kalimantan \\
\hline
\end{tabular}


Furthermore, data and information on the opinions represented by academics, practitioners, and regulators are structured in the form of a framework model. All responses are analysed using the "Super Decision" software.

\section{An Overview of the ANP Method}

This research uses the Analytic Network Process (ANP) method, which is a new approach in the qualitative method for a decision making process. ANP is a general theory of relative measurement used to derive a composite priority ratio from an individual ratio scale that reflects relative measurements of the effects of interacting elements concerning control criteria (Saaty, 2001). This method was first developed by Thomas L Saaty, as the development of the Analytic Hierarchy Process (AHP) method.

ANP is a new approach in the decision-making process without making assumptions. The advantage of ANP compared to other methodologies is its ability to measure and synthesize several factors in the hierarchy or network. No other methodology has synthesis featured such as ANP methodology. ANP is a mathematical theory that allows one to deploy dependencies and feedback in a systematic way that captures and combines tangible and intangible factors.

ANP is a new approach in the decision-making process that provides a common framework for treating decisions without making assumptions about the independence of higher level and lower level elements and the independence of elements within a level. Unlike the Analytic Hierarchy Process (AHP), ANP can use the network without having to set the level as in the hierarchy used in AHP. The main concept in ANP is an influence, while the main concept in AHP is a preference. AHP, with its dependency assumptions about clusters and elements, is a special case of ANP.

Ascarya explained (2005) that ANP has an advantage, which is the ability to assist researchers in measuring the synthesis of several factors in the network. In addition, the simplicity of the concept makes ANP a more general and easier methodology to be applied in diverse qualitative studies such as decision making, forecasting, evaluation, mapping, strategizing, resource allocation and so on. In addition, the ANP framework offers are more objective comparisons, more accurate predictions, and more stable results.

\section{BOCR Analysis}

According to Saaty and Vargas (2006) on research with BOCR network, the relationship between benefit, opportunity, cost and risk is influenced by common 
factors. Analysis of Benefit, Opportunity, Cost, Risk (BOCR) is a priority analysis based on the result of the desired criteria calculation as the benefit, and the unwanted criterion as the cost. In addition, there are also criteria based on future events, which may occur as a positive thing (opportunity) and things that can lead to risks.

The network structure of BOCR can also be divided into two clusters, namely the positive and negative effects of the problems studied. For more details can be seen as follows:

1. Benefit: all things that can provide benefits or advantages for the community with the BMT in developing border areas.

2. Opportunity: all things that can bring benefits or advantages for the community in the future as the result of the BMT in developing border areas.

3. Cost: all things that can cause burden or loss for the community with the BMT in developing border areas.

4. Risk: all things that can cause burden or loss for the community in the future as a result of the BMT in developing border areas.

Saaty and Vargas (2006) also describe the results of some prioritized alternatives, derived from three outcomes: 1) standard conditions obtained from the B / C; 2) Pessimistic B / (CxR); 3) and Realistic (BxO) / (CxR) calculations. The best alternative chosen is that with high realistic value; and the chosen alternative is considered as a decision determined from other alternatives. This realistic value is also similar to other Saaty's theory, where there are two types of calculations produced by BOCR. Among others:

a) Additive negative formula $=$ This formula is usually used to define long-term priorities, by the formula of $\mathrm{bB}+\mathrm{oO}-\mathrm{cC}-\mathrm{rR}$.

b) Multiplicative Formula $=$ This formula is equivalent to marginal cost/benefit analysis and is commonly used to define short-term priorities, with the formula of $\mathrm{BO} / \mathrm{CR}$.

\section{Discussion}

\section{Problem Analysis}

This part identifies and structures the complexity of the problem into the BOCR network. In-depth interview is one of the phases in research employing BOCR network. The literature review is also an important step in the problem description. So the problems gained from the literature review will be taken into account to be validated through in-depth interviews.

Interviews were conducted to respondents consisting of 3 academics, three 
practitioners, and three regulators. These respondents are considered to have a more advanced understanding of the research problems. Then the research framework is divided into five clusters, namely Benefit, Opportunity, Cost, Risk, and Alternative Strategies. Here is an explanation of the clusters:

1. Benefit

a. The practice of sharia economics

BMTs offer Islamic transactions in areas that cannot be served other by sharia business units. Thus, BMTs is able to distance the community from non-sharia economic practices.

b. Access to capitals

BMTs are close to rural areas making them more accessible and be able to cope with capital problems experienced by small traders.

c. A solution to the search of formal financial institutions

BMTs are able to reach areas that have not been reached by formal financial institutions such as banks.

d. Protection and social security.

In addition, the financial services and the real sectors, BMTs also work in social areas such as zakat, infāq and sadaqah.

2. Opportunity

a. The creation of an EMAS village

BMTs will be able to create an entrepreneur, independent, safe and prosperous village, and free from poverty and unemployment.

b. The practice of sharia-based economic

BMT's economic activity is operated in accordance with sharia, one of which uses a profit and loss sharing system. This provides convenience to the community by eliminating interests that can grow continuously.

c. Equity and economic justice

BTMs create economic justice with social activities (zakat, infāq, and sadaqah) and financial services activities (funding and lending).

d. The reduction of poverty.

BMTs can reduce poverty through the opening up of business opportunities and social activities such as zakat.

3. Cost

a. The absence of regulations.

The absence of special regulation related to BMT and border areas leads to 
poor performance and affects the operational efficiency of BMTs. So this may lead to bankruptcy.

b. Deposit Insurance Corporation.

This results in the distrust of the public to deposit funds in BMT.

c. The lack of mentoring for BMT's personnel.

The establishment of BMT is still unbalanced with the professional knowledge, experience, and skills of its personnel. This makes BMTs be not optimal carrying out the advisory, counselling, coaching, and supervision roles.

d. The lack of understanding of BMT.

The public still sees that BMT is similar to a conventional cooperative, but with more advantages compared to other MFIs, both in terms of products and services.

4. Risk

a. The possibility of regulatory changes.

There is the possibility of stricter supervision and regulation as well as increasingly difficult procedures or requirements, as well as the standardization of the feasibility and parameters of BMT health.

b. The possibility of religious and social conflict.

BMTs are known as Islamic cooperatives, and the operational of BMT is exclusively based on Islamic teaching, which may lead to emotional bonds. Social jealousy from other religious adherents may occur.

c. The default possibility

The success rate of the customers' business is an important factor affecting BMT revenue. However, the success rate of customers depends on their level of education and skills.

d. The vulnerability of moral hazard

Inadequate managerial systems and unscrupulous managers can lead to moral hazard. This can trigger the withdrawal of funds on a large scale, and BMT capital becomes limited.

5. Alternative Strategy

a. Linkage program

This can be done by conducting a cooperation program with Sharia Commercial Bank and SMFI. This is expected to result in knowledge transfer and managerial skills. 
b. Capital from third parties

BMTs conduct special cooperation with the government, non-government and private parties to obtain capitals, such as the village management funds, cash transfer funds (Bantuan Langsung Tunai), or company social responsibility funds. Capitals from the third parties aim at strengthening the capital of BMT, for its operational activities and funding activities of its customers.

c. Special regulations

The central and local government are encouraged to issue special regulations on BMT or cooperate with other parties to issue special regulations in favor of BMT in the development. So, BMT's role becomes more efficient and gains more trust from the community.

\section{Mean Geometric Results of the BOCR Model}

Based on the results of data processing, the value of the agreement shows that the potentials of BMT in developing border areas of Indonesia (West Kalimantan, Sambas) - Malaysia (Sarawak) can be divided into four models: BMT as a benefit, BMT as an opportunity, BMT as cost, or BMT as a risk. First, according to all respondents, BMT is a benefit. This means that BMT is an advantage for Indonesia in developing the border region (West Kalimantan, Sambas) - Malaysia (Sarawak). Second, BMT is an opportunity, which means that BMT offers an advantage in the future related to its potential in developing border area of Indonesia (West Kalimantan, Sambas) - Malaysia (Sarawak). These two factors, then, are followed by the cost and risk. This is supported by a high rater agreement of three categories of respondents, where the total value of the overall agreement of respondents by 55 percent $(\mathrm{W}=0.55)$.

Figure 1. Priority of Benefit, Opportunity, Cost, and Risk

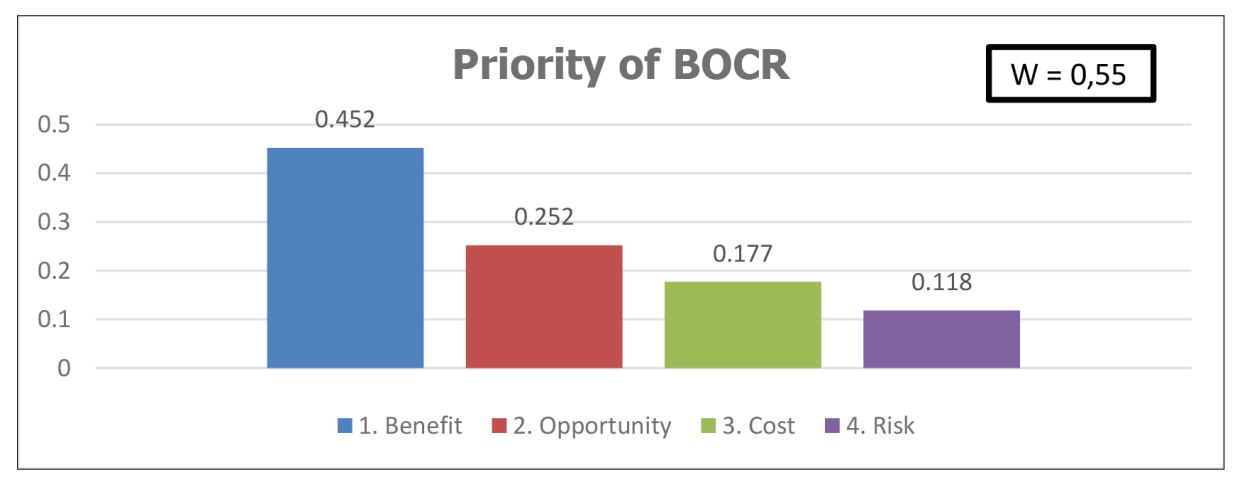


The benefits aspect is the highest priority with a weight value of 0.45 , followed by the opportunity aspect, with a weight value of 0.25 . The third priority is the cost aspect with the weight of the value of 0.17 , and the fourth priority aspect is the risk with a weight value of 0.11 . Overall, BMT's potential in developing Indonesia-Malaysia border areas is good since benefits and opportunities are more significant than the costs and risks. This concludes that BMT is recommended to be an alternative development of the Indonesia-Malaysia border region by prioritizing the welfare approach.

\section{Geometric Mean Cluster Benefit}

According to all respondents, getting access to capital is the priority with a weight value of 0.075 . This is in accordance with research conducted by Rozalinda (2013), which states that BMT is able to cope with capital problems faced by small micro traders. Meanwhile, one of the economic activities that run in the border region of Indonesia (West Kalimantan, Sambas) - Malaysia (Sarawak) is trading (Afrizal, 2009). The priority of benefit, according to all respondents, is to practice sharia, with a weight value of 0.069 . This is in accordance with the study of Arifin (2002), stating that BMT is able to distance the community from non-sharia economic practices. The priority of benefit, according to all respondents, has a value agreement (rater agreement) of 24 percent $(\mathrm{W}=0.24)$.

Figure 2. Priority of Benefit

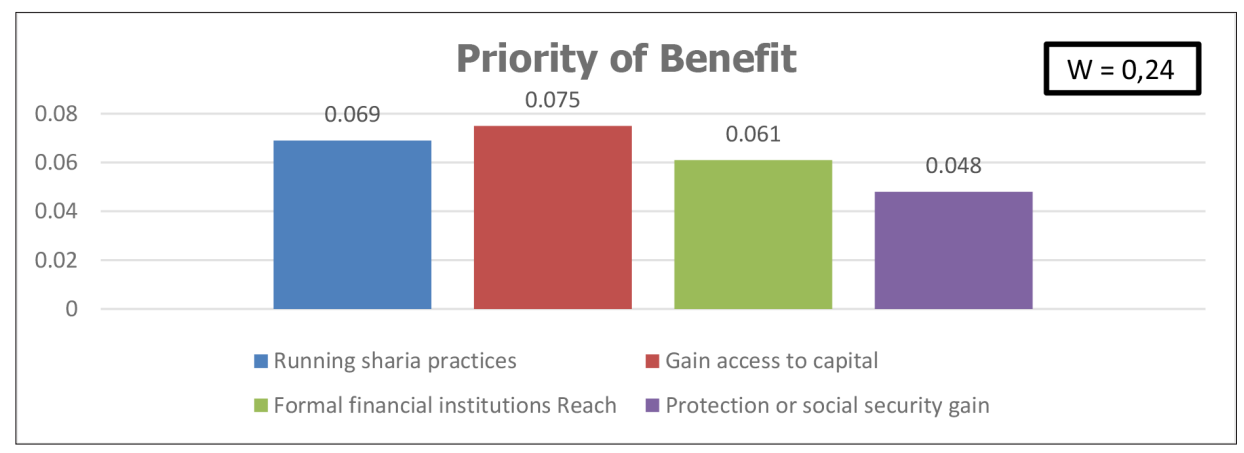




\section{Geometric Mean Cluster Opportunity}

All respondents agree that comfortability with sharia practices is the first priority with a weight of 0.076 value. This is because BMT is a Sharia Micro Finance Institution (SMFI) based on mutual cooperation, kinship, and mutual help (Mikhriani, 2011). In terms of religion, the majority population that live in the border region of Indonesia (West Kalimantan, Sambas) - Malaysia (Sarawak) is Muslims. They have a harmonious social life by giving priority to togetherness and mutual cooperation (Huruswati et al., 2012). So, with the presence of BMT among the community of border areas like that, the public will feel comfortable in practising the sharia.

The second priority, according to all respondents, is to alleviate poverty, with a value of 0.062 . This is in accordance with research conducted by Sriyana and Raya (2013), stating that BMT can reduce the poverty rate of the community, whether it is by opening up business opportunities for the community (Sumitro, 1996), or by sponsoring the poor (Hamid, 2003). The priority aspect of this opportunity has the value of the agreement (rater agreement) of all respondents by 20 percent $(\mathrm{W}=0.2)$.

Figure 3. Priority of Opportunity

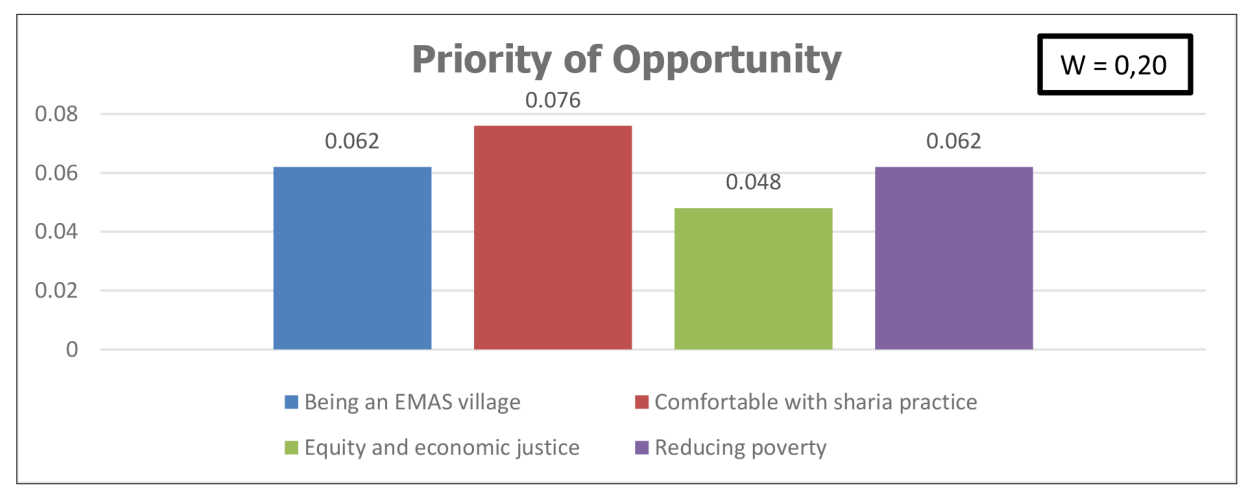

\section{Geometric Mean Cluster Cost}

According to all respondents, the lack of mentoring is the first priority with a weight of 0.072 . BMTs as microfinance institutions must play an active role in performing their functions, which include assistance, counselling, guidance and supervision of businesses owned by customers (Huda and Heykal, 2010). Sadrah (2004), however, says that the establishment of BMT is not balanced with professional knowledge, experience, and skills. So, BMT tends to be less effective in performing its functions as a financial institution. 
The second priority, according to all respondents, is minimal understanding of BMT with a weight value of 0.068. This is in accordance with research conducted by Irawan et al. (2013), where the result of the research indicates that there is still a perception among the community that the conventional cooperative does not have differences with the sharia cooperative (BMT). This perception will be a disadvantage for the community because it means that the people have a little knowledge about the existence of BMT, its terms and services, as well as its advantages compared to other microfinance institutions (Rusydiana and Devi, 2013). The priority cost has the value of the agreement (rater agreement) of all respondents by 42 percent $(\mathrm{W}=0.42)$.

Figure 4. Priority of Cost

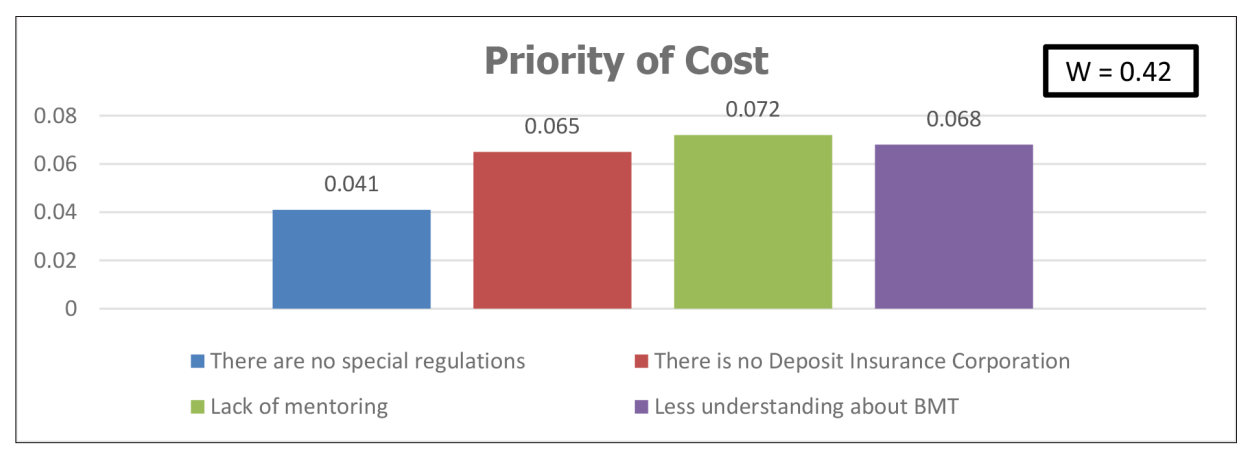

\section{Geometric Mean Cluster Risk}

All respondents agree that the possibility of default is the first priority of risk aspect with a weight of 0.07 . This is because the level of education and skills of the small community is relatively low. This is espoused by BMT's personnel's lack of professional knowledge, experience, and skills (Sadrah, 2004). As a result, this has an impact on the undeveloped business and the possibility of default. And the second priority is moral hazard vulnerability with a weight value of 0.066 . This is in accordance with the previous argument by Sadrah (2004), stating that the establishment of BMT is not balanced its personnel's professional knowledge, experience, and skills. That will lead to a less professional managerial system, and the managers are likely to violate the amannah or integrity (Santoso, 2003). This, in turn, will cause mistrust from society to BMT. The priority of this risk aspect has a total agreement value (rater agreement) of 64 percent $(\mathrm{W}=0.64)$. 
Figure 5. Priority of Risk

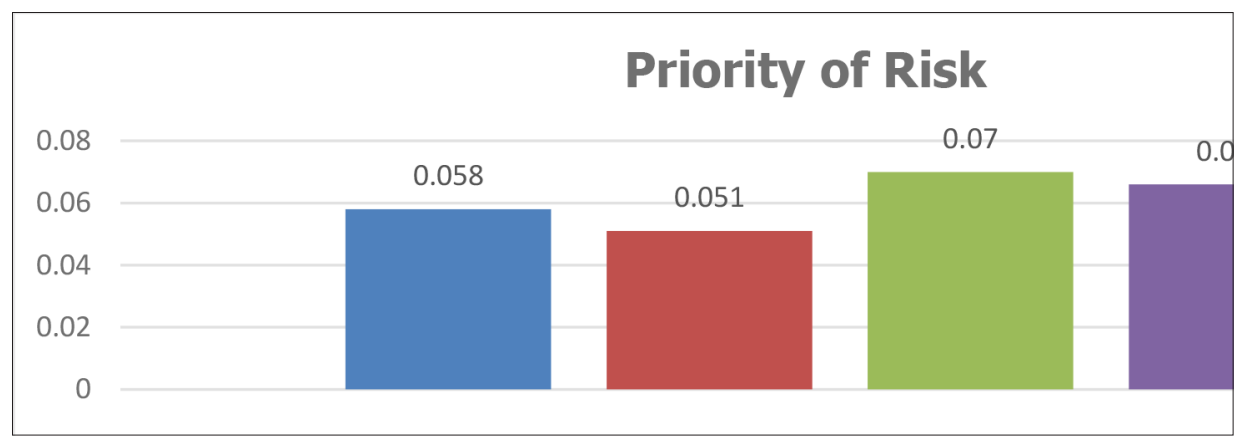

\section{Alternative Priorities}

In order to determine the priority sequence of the main alternatives in discussing the role of BMT in developing Indonesia's border region in Sambas, West Kalimantan, ANP analysis is used. Based on the previous data processing, responses from all respondents shows the value of the agreement of 55 percent $(\mathrm{W}=0.55)$. Therefore, alternative strategies needed to increase the potential of BMT, which include linkage programs, capital from third parties, and special regulation on BMT management.

Related to the priority in the alternative strategies, the respondents are in agreement that the first priority is the capital from third parties with a weight value of 0.44 . This priority is in accordance with the research conducted by Irawan et al. (2013), which found that in order to be able to contribute optimally in developing border areas, cooperation with third parties such as government and private institutions is required. Thus, the existence of alternative capital from third parties is an important alternative strategy, both in terms of management of village funds from the government or the management of CSR funds from companies.

Next, the linkage program becomes the second priority in alternative strategies. This program is to increase the potential of BMT in developing border area of Indonesia (West Kalimantan, Sambas) - Malaysia (Sarawak) with the weight of value 0.293. Research conducted by Sakti (2013) maintains that BMT faces four obstacles: capital problems, human resource competency problems, non-conducive regulatory issues, and competition issues. This alternative strategy will provide benefits not only in the financial aspects but also in the aspects of knowledge transfer and managerial skills. So the potential of BMT in developing border area of Indonesia (West Kalimantan, Sambas) - Malaysia (Sarawak) become larger.

The third priority is to seek a special regulation for BMT with a weight 
value of 0.265 . The existence of this special regulation is important to make BMT healthy and strong financial institutions that meet the standards and conditions (Sakti, 2013). The regulation is expected to improve the operational performance of BMT so that it becomes more efficient and gains more trust from the community. The priority of alternative strategy is supported by a rater agreement or high agreement value of the three categories of respondents, which amounted to 44 percent $(\mathrm{W}=0.44)$.

Figure 6. A priority of Alternative Strategy

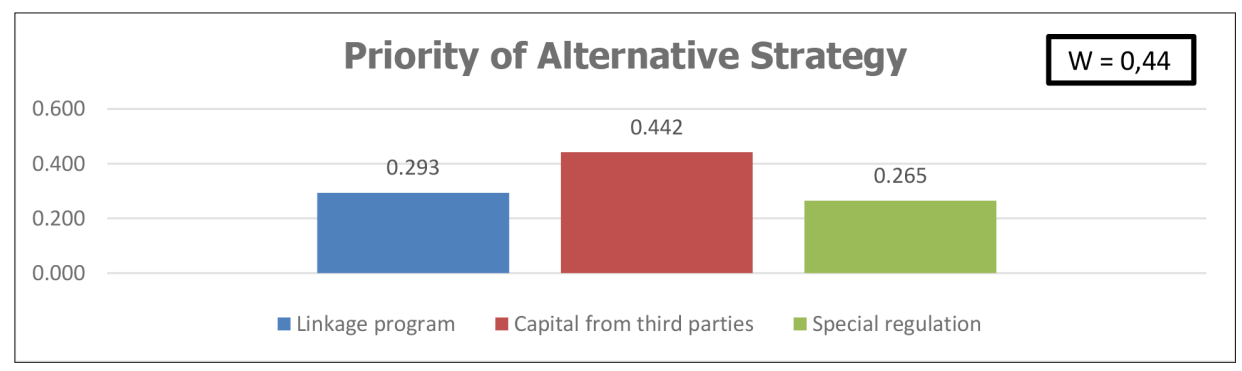

\section{Conclusion}

Indonesia - Malaysia border region is an area that must be paid attention by the government due to its role as the entrance of economic activities. The development of border areas with security approach alone is no longer effective. This approach needs to accompanied by the welfare approach. BMT, as one of Sharia Micro Financing Institutions, has the potential to play roles in the development of the border area of Indonesia (West Kalimantan, Sambas) - Malaysia (Sarawak) through welfare approach.

The analysis of in-depth interview results and previous literature reviews concludes that BMT has a potential in the development of Indonesia-Malaysia border regions. Benefits to be received by the community are to practice sharia, to have access to capital, to have access to formal financial institutions, and to obtaining protection or social security. Meanwhile, the opportunities that will be accepted by the community are to be an EMAS village; to have comfortable sharia practices; to experience equity and economic justice and to be exempted from poverty. The costs that may be faced by the community is no special regulation applied, no guarantor institution, lack of assistance and guidance, and minimal understanding of BMT by the people. The risks that will be faced by the public is the possibility of regulatory changes, religious and social conflict, the possibility of default, and vulnerability 
of moral hazard. Lastly, there are three alternative strategies to be implemented in order to maximize the benefits and opportunities, and minimize the burdens and risks, according to all respondents. These strategies are the capital of third parties, linkage programs, and special regulations.

\section{References}

Afrizal. 2009. "Potensi Pembiayaan Usaha Mikro, Kecil, dan Menengah oleh Perbankan di Wilayah Perbatasan Kalimantan Barat." Jurnal Aplikasi Manajemen 7(2): 484-496.

Arifin, Zainul. 2002. Dasar-Dasar Manajemen Bank Syariah. Jakarta: Penerbit Alvabet.

Ascarya. 2005. Analytic Network Process (ANP): Pendekatan Baru Studi Kualitatif. Jakarta: Bank Indonesia Pusat Pendidikan dan Studi Kebangsentralan BANK INDONESIA.

Bangun, Budi Hermawan. 2014. "Membangun Model Kerjasama Pengelolaan Perbatasan Negara di Kalimantan Barat - Serawak." Jurnal MMH 43(1): 31-39.

Danupranata, Gita. 2006. Ekonomi Islam. Cetakan I, UPFE-UMY.

Dardak, Hemanto. 2007. Percepatan Pembangunan Infrastruktur di Daerah Perbatasan Dalam Rangka Pembangunan Nasional. Jakarta: Direktorat Jenderal Binamarga Departemen Pekerjaan Umum.

Djafar, Zainuddin. 2008. "Masyarakat Perbatasan RI-Malaysia dan Kasus Askar Wataniah: Relevansi Perubahan Kebijakan Kesejahteraan." Jurnal Masyarakat dan Budaya 10(1): 103-122.

Hafifuddin, Didin. 2003. Manajemen Syariah Dalam Praktik. Depok: Gema Insani Press.

Hamid, Lutfi. 2003. Jejak-Jejak Ekonomi Syariah. Jakarta: Senayan Abadi Publishing. Hosen, M. Nadratuzzaman. 2006. Buku Saku Bank-ku Syariah. Jakarta: Pusat Komunikasi Ekonomi Syariah.

Huda, Nurul dan Muhammad Heykal. 2010. Lembaga Keuangan Islam, Tinjauan Teoritis dan Praktis. Jakarta: Kencana Prenada Media Group.

Huruswati, Indah, Alit Kurniasari, Agus Budi Purwanto \& Muhammad Sabeni. 2012. Evaluasi Program Pembangunan Kesejahteraan Sosial di Desa Perbatasan Kalimantan Barat. Cetakan I. Jakarta: P3KS Press.

Irawan, Dedik, Muhamad Irfan Affandi \& Umi Kalsum. 2013. "Analisis Strategi Pengembangan Lembaga Keuangan Mikro Syariah (LKMS) Pedesaan (Studi Kasus BMT Al Hasanah Sekampung)". JIIA 1(1): 1-9. 
Ishak, Awang Faroek. 2003. Membangun Wilayah Perbatasan Kalimantan Dalam Rangka Memelihara dan Mempertahankan Integritas Nasional. Jakarta: Indomedia.

Kurniadi, Dendy. 2009. Strategi Pengembangan Wilayah Perbatasan Antarnegara: Memacu Pertumbuhan Ekonomi Entikong Kabupaten Sanggau Provinsi Kalimantan Barat. Tesis. Program Studi Magister Teknik Pembangunan Wilayah dan Kota, Pasca Sarjana Universitas Diponegoro; Semarang.

Mayona, Enni Lindia, Salahudin \& Rahmi Kusmastuti. 2011. "Penyusunan Arahan Strategi dan Prioritas Pengembangan Perbatasan Antar Negara Di Provinsi Kalimantan Barat." Jurnal Tata Loka 13(2). Biro Penerbit Planologi UNDIP. Mikhriani. 2011. "Koperasi dan BMT: Sebuah Fenomena Sumber Dana Untuk Kemaslahatan Umat." Jurnal Dakwah 11(1): 33-52.

Mukti, Sri Handoyo. 2003. "Konsep Pengembangan Kawasan Perbatasan Kalimantan Indo-Malay Techno Agropolitan Corridor (IMTAC).” Buletin Tata Ruang (September-October): 8-9.

Nasikun. 1996. Urbanisasi dan Kemiskinan di Dunia Ketiga. Yogyakarta: PT. Tiara Wacana Yogya.

Peraturan Presiden Nomor 5 Tahun 2010. Tentang Rencana Pembangunan Jangka Menengah Nasional (RPJMN) 2010-2014.

Ridwan, Muhammad. 2005.Manajemen Baitul Maal wa Tamwil. $1^{\text {st }}$ ed. YogyakartaL UII Press.

Rozalinda. 2013. "Peran Baitul Maal Wa Tamwil (BMT) Taqwa Muhammadiyah Dalam Membebaskan Masyarakat Dari Rentenir di Kota Padang." INFERENSI Jurnal Penelitian Sosial Keagamaan 7 (2). Desember 2013.

Rusydiana, Aam S \& Abrista Devi. 2013. "Challenges in Developing Baitul Maal wat Tamwil (BMT) In Indonesia Using ANP." Bussiness and Management Quarterly Review 4(2): 51-62.

Saaty, Thomas L., 2001. Theory and Applications of the Analytic Network Process. Pittsburgh: University of Pittsburgh.

Saaty, Thomas L \& Louis G Vargas. 2006. Decision Making with the Analytic Network Process. Economic, Political, Social and Technological Applications with Benefits, Opportunities, Costs and Risks. Pittsburgh: Springer. RWS Publication.

Sadrah, Engkos. 2004. BMT dan Bank Islam. Bandung: Pustaka Bani Quraisy.

Sakti, Ali. 2013. "Pemetaan Kondisi dan Potensi BMT: Kemitraan Dalam RangkaMemperluas Pasar dan Jangkauan Pelayanan Bank Syariah Kepada Usaha Mikro." Jurnal al-Muzara'ah 1(1). 
Salam, Annisa Nur, Hana Putri Rahmania \& Neneng Ela Fauziyyah. 2014. Model Optimalisasi Lembaga Keuangan Mikro Syariah (LKMS) Dalam Rangka Pengembangan dan Pemberdayaan Wilayah Pedesaan. Fakultas Ekonomi dan Bisnis Islam, Universitas Islam Negeri Sunan Kalijaga; Yogyakarta.

Santoso, B. S. 2003. "Analisis Tingkat Kesehatan BMT Ditinjau Dari Aspek Manajemen." Jurnal Akuntansi-Bisnis \& Manajemen (Oktober 2003).

Sriyana, Jaka \& Fitri Raya. 2013. "Peran BMT Dalam Mengatasi Kemiskinan di Kabupaten Bantul." INFERENSI Jurnal Penelitian Sosial Keagamaan 7(1).

Sudarsono, Heri. 2005. Bank dan Lembaga Keuangan Syariah: Deskripsi dan Ilustrasi. $2^{\text {nd. }}$ Yogyakarta: Penerbit EKONISIA FE UII.

Sudibyo, P. 2006. Ancaman Terhadap Kelestarian Sumber Daya Alam di Kawasan Perbatasan Negara. Penataan Ruang dan Daerah Perbatasan (Juli-Agustus): 6-8.

Sumarsono, S. 2012. Pembangunan Kawasan dan Manajemen Tasbara. Buku 2, Paket Sosialisasi Pengelolaan Lintas Batas Negara. Jakarta: Badan Nasional Pengelolaan Perbatasan, Kedeputian Batas Wilayah Negara.

Sumitro, Warkum. 1996. Asas-Asas Perbankan Islam dan Lembaga-Lembaga Terkait di Indonesia. Jakarta: PT Raja Grafindo Persada.

Suratman, Edy. 2008. Kawasan Perbatasan dan Pembangunan Daerah. Pontianak: Untan Press.

Susila, Ahdiyat Agus. 2014.Strategi Kesuksesan Koperasi BMT Maslahah Dalam Pengembangan Usaha dan Pemberdayaan Ekonomi Umat. Tesis. Konsentrasi Keuangan dan Perbankan Syariah Program Studi Hukum Islam Pasca Sarjana UIN Sunan Kalijaga, Yogyakarta.

Yunus, Jamal Lulail. 2009.Manajemen Bank Syariah Mikro. Malang: UIN Malang Press.

Yusuf, Sri Dewi. 2014. "Peran Strategis Baitul Maal Wa-Tamwil (BMT) Dalam Peningkatan Ekonomi Rakyat.” Jurnal al-Mizan 10(1). (Juni 2014).

Undang-Undang Nomor 25 Tahun 2000. Tentang Program Pembangunan Nasional. Law No. 43/ 2008 Concerning State Territory. 